\title{
Involvement of the gonococcal MtrE protein in the resistance of Neisseria gonorrhoeae to toxic hydrophobic agents
}

\author{
R. M. Delahay, ${ }^{1}$ B. D. Robertson, ${ }^{1}$ J. T. Balthazar, ${ }^{2}$ W. M. Shafer ${ }^{2,3}$ \\ and C. A. Ison ${ }^{1}$
}

Author for correspondence: C. A. Ison. Tel: +44 171594 3965. Fax: +44 1712626299.

e-mail: c.ison@ic.ac.uk

\footnotetext{
1 Department of Medical Microbiology, Imperial College School of Medicine at St Mary's, Norfolk Place, London W2 1PG, UK

2 Laboratories of Microbial Pathogenesis, Medical Research Service, VA Medical Center (Atlanta), Decatur, GA 30033, USA

3 Department of Microbiology and Immunology, Emory University School of Medicine, Atlanta, GA 30322, USA
}

\begin{abstract}
Low-level resistance of Neisseria gonorrhoeae to toxic hydrophobic agents (HAs), including some antibiotics, is chromosomally mediated via the multiple transferable resistance ( $m$ tr) efflux system. The gene encoding the $48.3 \mathrm{kDa}$ outer-membrane protein MtrE, which is associated with the mtr phenotype, was identified and is homologous to export-associated outer-membrane proteins, including the OprM (formerly OprK) lipoprotein of Pseudomonas aeruginosa. Insertional inactivation of the $\boldsymbol{m t r E}$ gene in $\boldsymbol{N}$. gonorrhoeae strain FA19 resulted in the loss of the outer-membrane protein, with concomitant hypersusceptibility of the mutant strain to a range of HAs. The properties of this mutant confirmed the role of MtrE in multidrug resistance mediated by an active efflux mechanism. Secondary structure predictions for MtrE indicated a largely hydrophilic protein with a single $\alpha$-helical transmembrane region. A transposon-like element, similar to that found downstream of the region containing the promoters for $m$ trR and $m t r C$ in Neisseria meningitidis, was identified 63 bp downstream of the mtrE gene.
\end{abstract}

Keywords: Neisseria gonorrboeae, efflux, hydrophobic agents, antimicrobial resistance, MtrE

\section{INTRODUCTION}

The ability of Gram-negative bacteria to resist the toxic action of a variety of structurally diverse hydrophobic agents (HAs), including antimicrobials, appears to be due to synergism between the impermeability of the outer membrane and active efflux mechanisms (Nikaido, 1994). The multiple transferable resistance or $\mathrm{mtr}$ phenotype in Neisseria gonorrhoeae is associated with increased resistance to inhibitory HAs, and recent studies have determined that the $m t r$ locus encodes an active efflux mechanism (Hagman et al., 1995; Lucas et al., 1995). The prevalence of $m$ tr strains in rectal isolates, compared to the relative HA sensitivity of strains isolated from other sites, has led to the proposal that the resistant phenotype confers a survival advantage on gonococci in environments which contain high concentrations of inhibitory detergent-like agents, including bile salts, steroids and fatty acids (Morse et al., 1982;

Abbreviation: HA, hydrophobic agent.

The GenBank/EMBL accession number for the $m$ trE nucleotide sequence reported in this paper is $\mathrm{X} 95635$.
Shafer et al., 1995). Molecular studies on the $m t r$ locus have shown that the resistant phenotype results from mutations in the coding (Pan \& Spratt, 1994) and promoter (Hagman et al., 1995; Hagman \& Shafer, 1995) region of one gene in the $m t r$ operon, $m t r R$.

$m t r R$ encodes a putative transcriptional repressor (Hagman et al., 1995) and is located upstream and divergent from the single $m t r C D E$ transcriptional unit encoding the structural components of the efflux system. By virtue of homology to components of the acrRAB and acrSEF systems of Escherichia coli and the mexABoprM system of Pseudomonas aeruginosa, which are important in determining resistance to multiple antibiotics $(\mathrm{Ma}$ et al., 1993; Poole et al., 1993), it appears that $m t r D$ encodes an inner-membrane transporter of the resistance/ nodulation/cell division (RND) family (Saier et al., 1994), and that $m t r C$ encodes the associated periplasmic-spanning membrane fusion protein. $m$ trE is proposed to encode an outer-membrane protein completing a system likely to translocate HAs across both membranes in a single step (Nikaido, 1994).

We report here the cloning of the $m t r E$ gene, and show that the derived MtrE protein is homologous to the 
outer-membrane protein OprM of $P$. aeruginosa, and to members of the outer-membrane factor (OMF) family (Fath \& Kolter, 1993), which are associated with singlesubstrate transporters.

\section{METHODS}

Bacterial strains and growth conditions. The isogenic, non- $\beta$ lactamase producing $N$. gonorrhoeae strains FA19 (wild-type, $\mathrm{HA}^{\mathrm{S}}$ ) and FA136 (penA, $m$ trR-171, $\mathrm{HA}^{\mathrm{R}}$ ) were described by Sparling et al. (1975). Strain KH15 (mtrR-171, $\mathrm{HA}^{\mathrm{R}}$ ) was constructed by transformation of piliated $\left(\mathrm{P}^{+}\right)$FA19 with PCR-amplified DNA corresponding to the $m t r R$ region of strain FA171 (mtrR-171, HA $^{\mathrm{R}}$ ) (Hagman et al., 1995). Strains FA136 and KH15 both contain a single base pair deletion in the $13 \mathrm{bp}$ inverted repeat located within the $m t r R$ promoter region. Gonococci were routinely grown as $\mathrm{P}^{+}$colonies on $\mathrm{GC}$ agar base (Difco) containing $1 \%(\mathrm{w} / \mathrm{v})$ IsoVitaleX (Becton Dickinson) at $36{ }^{\circ} \mathrm{C}$, under $5 \%(\mathrm{v} / \mathrm{v}) \mathrm{CO}_{2}$. E. coli strains XL1-Blue MRF and SOLR were obtained from Stratagene and grown on LB agar, or in LB broth at $37^{\circ} \mathrm{C}$ with shaking. Media contained either $12.5 \mu \mathrm{g}$ tetracycline $\mathrm{ml}^{-1}$, $50 \mu \mathrm{g}$ kanamycin $\mathrm{ml}^{-1}$ or $100 \mu \mathrm{g}$ ampicillin $\mathrm{ml}^{-1}$, as appropriate.

Production of polyclonal antisera against gonococcal outermembrane proteins. Outer-membrane proteins were isolated from overnight plate cultures of FA136 by Sarkosyl extraction (Guymon et al., 1978). Proteins were separated by SDS-PAGE, transferred to nitrocellulose and stained with Ponceau $S$. Protein bands of $48-52 \mathrm{kDa}$ were excised, destained and dissolved in $250 \mu$ l acetone in the barrel of a glass Luer-lock syringe. Following evaporation of the acetone, the proteins were redissolved in $250 \mu \mathrm{l}$ PBS $(0.137 \mathrm{M}$ sodium chloride, $0.0027 \mathrm{M}$ potassium chloride, $0.015 \mathrm{M}$ potassium dihydrogen phosphate, $0.08 \mathrm{M}$ disodium hydrogen phosphate), then mixed in situ with $250 \mu$ l Freund's complete adjuvant (Difco). One hundred microlitres of suspension was used to immunize each of three female Balb/c mice intraperitoneally. Subsequent boosts were delivered intraperitoneally in Freund's incomplete adjuvant (Difco) at 2 week intervals. Immune responses were monitored by Western blots. The antiserum was enriched for antibody specific for the $48-52 \mathrm{kDa}$ proteins by mixing 20 excised and blocked [5\% (w/v) nonfat dried milk in PBS] nitrocellulose strips carrying the proteins with $10 \mu$ lantisera for $3 \mathrm{~h}$ at $37^{\circ} \mathrm{C}$. Strips were subsequently washed and absorbed antibody dissociated by the addition of $0.5 \mathrm{ml}$ $100 \mathrm{mM}$ glycine $\mathrm{pH} 2.5$; the supernatant was then immediately neutralized with $25 \mu \mathrm{l} 1 \mathrm{M}$ Tris $/ \mathrm{HCl} \mathrm{pH} \mathrm{8.0.} \mathrm{The}$ semi-purified antisera was also absorbed against whole $E$. coli XL1-Blue MRF cells.

Construction and immunoscreening of a lambda Zapll expression library of strain FA136. Chromosomal DNA for library construction was extracted from strain FA136 by the method of Stern et al. (1984), partially digested with $2 \mathrm{U}$ EcoRI $\mu \mathrm{g}^{-1}$, and fragments of $3-10 \mathrm{~kb}$ isolated on a $5-25 \%$ $(\mathrm{w} / \mathrm{v})$ sucrose gradient. DNA fragments were ligated to alkaline-phosphatase-treated lambda ZapII/EcoRI arms (Stratagene) and packaged into phage heads using Gigapack II Gold packaging extracts (Stratagene) according to the manufacturer's instructions. Both the ratio of recombinants to nonrecombinants $(45: 1)$, and the titre of the library $(1.35 \times$ $10^{7}$ p.f.u. $\mathrm{ml}^{-1}$ ) were favourable for immunological screening using the partially affinity-purified antiserum as probe. Positive plaques were purified and maintained as plasmid DNA following in vivo excision. All the positive clones analysed had an insert of $6.3 \mathrm{~kb}$.

Cloning and sequencing of $\boldsymbol{m}$ tre. Limited sequence data from the 5 -terminus of the $m t r E$ gene has been reported (Hagman et al. 1995). Forward and reverse primers (mtrE-F, 5'CCTTTGCATTGTCTGCCTGCAC-3', and its inverse complement, $m t r E-R$ ) were designed from this information and used in conjunction with M13 forward and reverse primers, which anneal to the $\mathrm{pBluescript} \mathrm{vector,} \mathrm{to} \mathrm{confirm} \mathrm{the} \mathrm{presence}$ of $m t r E$ within the $6.3 \mathrm{~kb}$ insert in plasmid pBSGC2. Cycling conditions for PCR $\left(94^{\circ} \mathrm{C}\right.$ for $1 \mathrm{~min}, 60^{\circ} \mathrm{C}$ for $1 \mathrm{~min}, 72^{\circ} \mathrm{C}$ for $3 \mathrm{~min}$; 30 cycles) were optimized for amplification of a $3 \mathrm{~kb}$ fragment, based on the assumption that $m t r E$ would be of a size similar to oprM (Poole et al., 1993). Products were only obtained with primer pairs $m t r E-F / M 13-F$ and $m t r E-\mathrm{R} / \mathrm{M} 13-$ $R$. Cycle sequencing was performed using kits from Toyobo and Cambridge Biosciences, and primer walking. The sequence was digitized using a digital gel reader and the MacVector program, and sequences were aligned using the AssemblyLIGN program (all IBI).

Homology searches of the GenBank/EMBL and SWISSPROT databases employed FASTA and TFASTA search programs from the GCG package (Devereux et al., 1984) available from the Human Genome Mapping Project, Cambridge. Representations of secondary structure were generated with GCG and MacVector software, using the statistical algorithms of Chou \& Fasman (1978) and Garnier et al. (1978). Multiple sequence alignment was achieved with the GCG programs PILEUP and PRETTYBOX. Hydrophobicity plots were derived from the algorithm of Kyte \& Doolittle (1982). Further predictions of secondary structure were attempted using the SAPS (statistical analysis of protein sequences) program of Brendel et al. (1992) and the PHD (profile network from Heidelberg) neural network, PredictProtein described by Rost \& Sander (1993), both available via the World Wide Web.

Insertional inactivation of $\boldsymbol{m t r E}$. The complete $m \boldsymbol{m} \boldsymbol{t} E$ gene was subcloned as a 2131 bp HincII/SmaI fragment from pBSGC2 into pBluescript to create pBSGC2-8. A null mutant, termed pBSGC2-8K, was constructed by replacing an internal $392 \mathrm{bp}$ StyI fragment with an 850 bp aphA-3 non-polar kanamycin resistance cassette which lacks a promoter and transcriptional terminator (Ménard et al., 1993). This cassette and any downstream genes in the $m$ tr operon will be transcribed from the $m t r$ promoter. Correct insertion of the cassette was confirmed by sequencing and Southern blotting (data not shown).

Piliated $\mathrm{HA}^{\mathrm{R}}$ gonococcal recipient strain KH15 $\left(1 \times 10^{8}\right.$ c.f.u. $\mathrm{ml}^{-1}$ ) was transformed with $0.5 \mu \mathrm{g} \mathrm{ml}^{-1}$ Bsal-linearized pBSGC2-8K in GCB broth (Difco) containing defined supplements I and II (Shafer et al., 1984), $2 \mathrm{mM} \mathrm{MgCl}_{2}$ and $0.043 \%$ $(\mathrm{w} / \mathrm{v})$ sodium bicarbonate at $36^{\circ} \mathrm{C}$ for $30 \mathrm{~min}$. One hundred microlitres of the transformation mix was plated on GC agar plates for $5 \mathrm{~h}$ at $36^{\circ} \mathrm{C}$ under $5 \% \mathrm{CO}_{2}$, then overlaid with top agar containing $50 \mu \mathrm{g}$ kanamycin $\mathrm{ml}^{-1}$. Incubation was continued for a further $24-48 \mathrm{~h}$. The $\mathrm{Kan}^{\mathrm{R}}$ transformant RD1 was isolated and used for MIC determination. Homologous recombination and allelic replacement was confirmed by Southern blotting using the $m t r E$ sequence as probe (data not shown); Western blotting experiments demonstrated the loss of a protein of a molecular mass corresponding to MtrE (data not shown).

\section{RESULTS}

\section{Isolation and analysis of a clone expressing immunoreactive protein}

Polyclonal antiserum was raised against proteins $(48-52 \mathrm{kDa})$ associated with the $m t r$ phenotype in the 
Table 1. Homology of MtrE with outer-membrane proteins associated with efflux/transport systems

\begin{tabular}{|c|c|c|c|}
\hline Organism & $\begin{array}{l}\text { Outer membrane } \\
\text { component }\end{array}$ & $\begin{array}{c}\text { Identity }(\%) \text { and } \\
\text { amino acid overlap }\end{array}$ & $\begin{array}{c}\text { Accession } \\
\text { numbert }\end{array}$ \\
\hline Pseudomonas aeruginosa & OprM & 40.9 in 465 aa overlap & L23839 \\
\hline Burkholderia cepacia & OpcM & 31.5 in 467 aa overlap & U38944 \\
\hline $\begin{array}{l}\text { Rhizobium } \\
\text { leguminosarum bv. } \\
\text { trifolii }\end{array}$ & NodT & $27 \cdot 2$ in 459 aa overlap & P24145 \\
\hline $\begin{array}{l}\text { Rhizobium } \\
\text { leguminosarum bv. } \\
\text { viciae }\end{array}$ & NodT & $27 \cdot 4$ in 464 aa overlap & P15727 \\
\hline Bordetella pertussis & CyaE & 24.0 in 459 aa overlap & P11092 \\
\hline Pseudomonas aeruginosa & AprF & 20.9 in 398 aa overlap & Q03027 \\
\hline Erwinia chrysanthemi & PrtF & 14.9 in 377 aa overlap & P23598 \\
\hline Alcaligenes eutrophus & $\mathrm{CzcC}$ & $20 \cdot 3$ in 301 aa overlap & P13509 \\
\hline Burkbolderia cepacia & FusA & 25.8 in 229 aa overlap & P24126 \\
\hline Escherichia coli & TolC & 22.6 in 186 aa overlap & P02930 \\
\hline
\end{tabular}

"Identity is expressed as a percentage of the total amino acid overlap.

† Numbers given for P. aeruginosa and B. cepacia refer to the GenBank/EMBL database, those for all other organisms to the SWISS-PROT database.

HA-resistant gonococcal strain FA136 (penA, $m$ tr-171). The antibody was affinity-purified and used to screen a lambda ZapII expression library made from the same strain. An immunoreactive clone, pBSGC2, containing a $6.3 \mathrm{~kb}$ insert was isolated. pBSGC2 directed the synthesis of a recombinant protein of approximately $50 \mathrm{kDa}$, which reacted with the polyclonal antibody by immunoblotting (data not shown).

Sequence data from the $5^{\prime}$-terminus of the $m t r E$ gene has been reported (Hagman et al., 1995) and was used to design primers for sequencing. This revealed the complete $m t r E$ ORF 52 bp downstream of the $m t r D$ TAA stop codon. This intergenic region contained a single copy of the gonococcal uptake sequence (Goodman \& Scocca, 1988) and a putative Shine-Dalgarno ribosomebinding site. No consensus promoter sequences were identified, but a putative transcriptional terminator consisting of a further copy of the uptake sequence and an inverted repeat was identified contiguous with the $m t r E$ stop codon. This strongly suggests that $m t r E$ is the last gene in the operon.

Abadi et al. (1996) recently analysed the $m t r R$ region in the meningococcus. It is $97 \%$ identical at the nucleic acid level to the corresponding gonococcal gene, but contains a $157 \mathrm{bp}$ insertion. This insertion is also found $62 \mathrm{bp}$ downstream of the gonococcal $m t r E$, in the form of an inverted repeat. The gonococcal element is $86 \%$ identical to the meningococcal unit. These sequences are homologous to the transposon-like elements described by Correia et al. (1988), multiple copies of which are known to occur in the genomes of pathogenic Neisseria spp.

\section{Homology of MtrE to other export proteins}

The $m t r E$ gene encodes a 467 amino acid protein of $50.4 \mathrm{kDa}$ with a 21 amino acid signal peptide, which includes a signal peptidase II cleavage site (residues 18-21), indicating post-translational modification of the prolipoprotein (Hayashi \& Wu, 1990). The recombinant protein from $E$. coli could be labelled with $\left[{ }^{3} \mathrm{H}\right]$ palmitate whereas cells containing the non-recombinant vector demonstrated no such labelling of a corresponding protein (data not shown), indicating that MtrE is a lipoprotein.

A search of the SWISS-PROT database identified a number of outer-membrane proteins associated with transport or efflux systems that are similar to MtrE (Table 1). Alignment of these protein sequences (Fig. 1) revealed two consensus motifs, consisting largely of hydrophobic non-polar residues, located between residues 339 to 344 , and 421 to 427 of MtrE. They may be represented as follows:

(i) (Leu/Ile/Val) $\mathrm{Xxx}$ (Leu/Val/Ile) Pro (Ile/Leu) (Phe/Leu/Tyr)

(ii) Leu Xxx (Leu/Val) Leu Xxx Ala (Gln/Glu) (Arg/Gln/Ser)

In both cases, the first residue listed in brackets is the most frequently encountered, and Xxx represents any residue. Neither motif appears in the TolC sequence. The first motif occurs in the remaining nine of the outermembrane proteins in Table 1, plus MtrE. The second motif is modified at two residues in the OpcM polypeptide. 


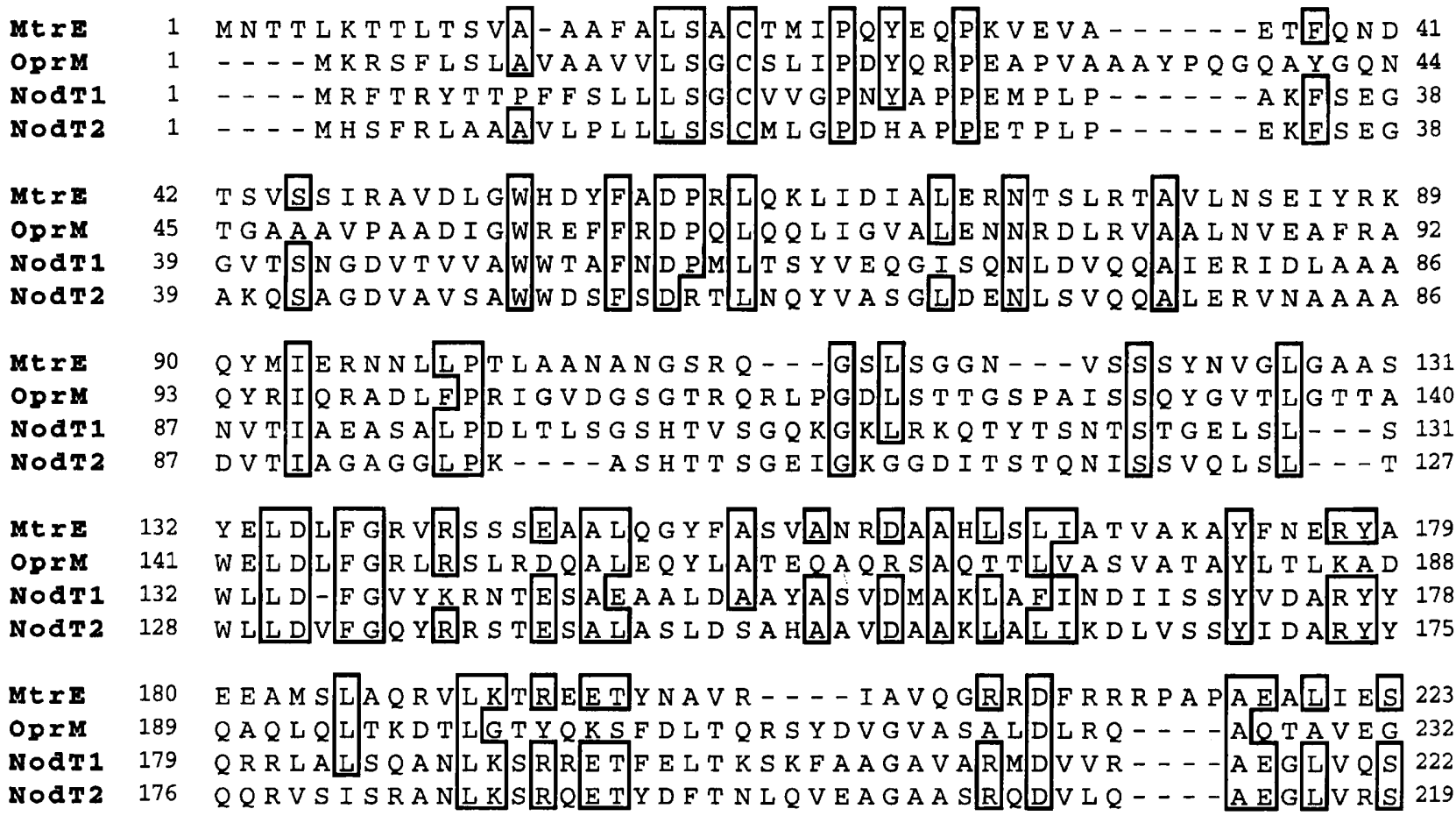

Mtr $\mathbf{E} \quad 224$

OprM 233

NodT1 223

NodT2 220

MtrE 269

OprM 277

NodT1 269

NodT2 266

Mtr $\mathbf{E} \quad 317$

OprM 325

NodT1 317

NodT2 314

Mtr $\mathbf{E} \quad 365$

OprM 373

NodT1 365

NodT 2361

Mtr $\mathbf{E} \quad 413$

OprM 421

NodT1 413

NodT 2409

MtrE 461 RDTQTGK $\ldots \ldots$

OprM 469 FDTCQKRAG - . - . . - . -

NodT1 461 PVAKAGL_-

NOAT2 457 APKVASPREASTVAAANANIQSAHSP

Fig. 1. Multiple amino acid alignment of the complete MtrE sequence from $N$. gonorrhoeae with three other outermembrane proteins, made using PILEUP and SeqVu. Each protein is the proposed outer-membrane component associated with transport/efflux systems. OprM, P. aeruginosa; NodT1, Rhizobium leguminosarum bv. trifoli; NodT2, Rhizobium leguminosarum bv. viciae. Homologous residues are outlined, and the two proposed consensus motifs are boxed. 
Table 2. Susceptibilities of gonococcal strains to a range of inhibitory HAs

\begin{tabular}{|lclrlr|}
\hline Strain & \multicolumn{5}{c|}{ MIC $\left(\boldsymbol{\mu g} \mathbf{~ m l}^{-1}\right)$ of :* } \\
\cline { 2 - 6 } & TX-100 & Ery & PA & CaA & ChA \\
\hline FA19 (wild-type) & 100 & $0 \cdot 25$ & 200 & 300 & 250 \\
KH15 (mtrR-171) & $>16000$ & $2 \cdot 0$ & 800 & $>500$ & $>500$ \\
RD1 & $2 \cdot 0$ & 0.06 & 50 & 100 & 100 \\
(mtrE::aphA-3) & & & & & \\
\hline
\end{tabular}

* TX-100, Triton X-100; Ery, erythromycin; PA, palmitic acid; CaA, capric acid; ChA, cholic acid. † Strain KH15 contains a single base pair deletion in the $13 \mathrm{bp}$ inverted repeat located in the $m t r R$ promotor region.

\section{Characterization of an $\boldsymbol{m t r E}$ null mutant}

To establish the importance of $\mathrm{MtrE}$ in the $\mathrm{HA}^{\mathbf{R}}$ phenotype mediated by the $m t r C D E$ complex, the $m t r E$ gene was inactivated as described in Methods. The effect of $m t r E$ inactivation in the $\mathrm{Kan}^{\mathrm{R}}$ transformant strain RD1 (mtrE::aphA-3) was established by the hypersusceptibility it demonstrated to a panel of HAs (Table 2), including the fatty acids palmitic acid and capric acid, and the bile salt, cholic acid. The loss of an individual efflux protein is apparently sufficient to cause a complete collapse of the $m t r$ system, with consequent loss of the resistant phenotype. No significant change in MIC was demonstrated between wild-type, $\mathrm{HA}^{\mathrm{R}}$ and $m t r E$ mutant strains to the hydrophilic fluoroquinolone ciprofloxacin.

\section{DISCUSSION}

We have cloned the gene for the outer-membrane component of the $m t r$ efflux system, $m t r E$. It is the last gene in the mtrRCDE operon (Fig. 2) and encodes a putative lipoprotein of $48 \cdot 3 \mathrm{kDa}$. The hydrophilic nature of the protein, identification of a signal sequence typical of exported proteins, and the homology it demonstrates to other established outer-membrane proteins, are all compatible with its expected location. However, preliminary secondary structure analysis of the MtrE polypeptide failed to unequivocally identify $\beta$-sheet structures which might be expected for a protein associated with the outer-membrane bilayer. In the case of porins, $\beta$-sheet structure predominates and the formation of a $\beta$-barrel has been suggested, both to determine the ultimate conformation of the protein in the membrane and to facilitate export to its final location (Nikaido \& Saier, 1992). Aside from a consistently strong indication of a single transmembrane $\alpha$-helix (residues 325-347), the membrane conformation of the polypeptide could not be elucidated on the basis of the available predictive algorithms.

MtrE demonstrates homology to a number of outermembrane proteins associated with transport/efflux systems. These include the OprM and OpcM lipoproteins associated with multidrug-resistance (MDR) efflux systems in $P$. aeruginosa and Burkholderia cepacia, respectively (Poole et al., 1993; Burns et al., 1996), and the NodT export proteins of Rhizobium spp. (Surin et al., 1990; Economou et al., 1990).

Limited homology has been established with the outer
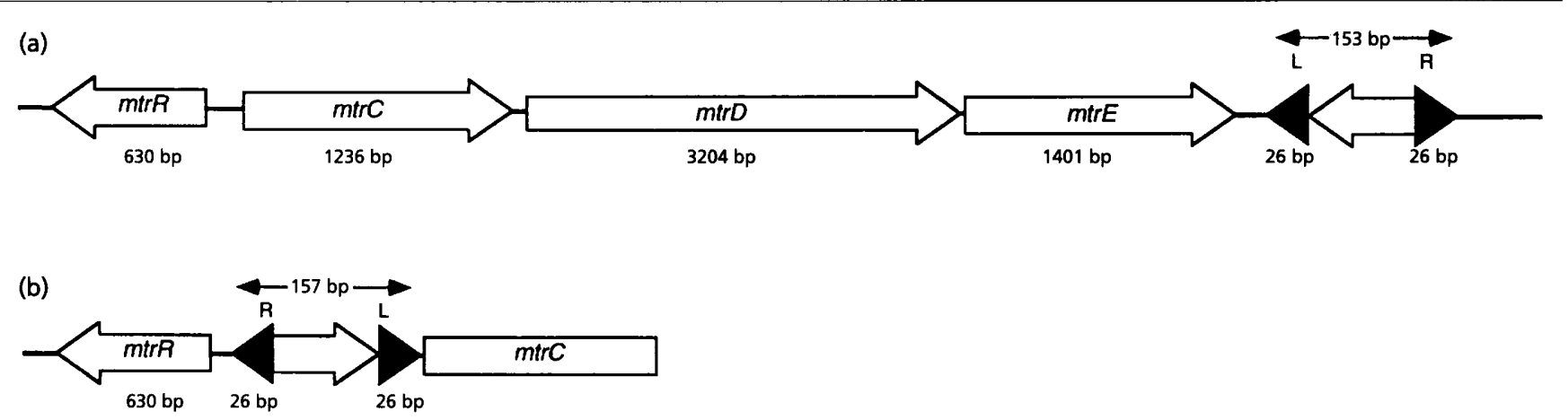

Fig. 2. Organization of the mtrCDE region of $N$. gonorrhoeae (a) and the corresponding region in Neisseria meningitidis (b). Transposon-like elements are orientated and labelled according to the nomenclature of Correia et al. (1988). The elements are flanked by inverted repeats of a 26 bp sequence, designated left $(L)$ and right (R). The element located downstream of the recently described promoter region of the mtrR and $m \operatorname{trC}$ genes of $N$. meningitidis (Abadi et al., 1996) is inverted with respect to the $N$. gonorrhoeae sequence, and displaces $m$ trC from its promoter. 
membrane transporters of the outer-membrane factor (OMF) family (Fath \& Kolter, 1993), which are predominantly associated with the transport of single physiological metabolites. Possibly these homologies reflect the broader substrate specificity of the MDRassociated outer-membrane proteins within a family of proteins likely to adopt similar structures in the outer membrane. The identification of conserved motifs within the polypeptide sequence of these proteins, consisting largely of hydrophobic residues, may be of relevance in this respect. The absence of these signatures within the TolC sequence is intriguing however, since the TolC protein is known to function in association with several export systems in a similar capacity to other OMF proteins (Fath \& Kolter, 1993; Fralick \& Burns-Keliher, 1994; Wang et al., 1991).

Analogous to a strain carrying an $m t r C$ null mutation (Hagman et al., 1995), loss of MtrE by insertional inactivation is sufficient to cause a collapse of the entire efflux system, indicating the requirement for all three structural proteins (MtrC, MtrD and MtrE) in the efflux process. The hypersensitivity to a variety of HAs demonstrated by these mutants argues in favour of an essential role for the efflux system in gonococcal survival, and highlights the importance of this mechanism in addition to the physical permeability barrier presented by the outer membrane. We cannot be sure that membrane disorganization resulting from the loss of MtrE does not impact upon any other membrane systems, or indeed that loss of MtrE does not have more pleiotropic effects similar to those demonstrated by the loss of the E. coli TolC lipoprotein (Morona et al., 1983). However, no changes in total cell-envelope proteins were observed in either Coomassie-Bluestained SDS-PAGE gels or Western blots probed with a polyclonal antiserum raised against whole cells of strain FA136 (data not shown).

The location of a 155 bp transposon-like element $62 \mathrm{bp}$ downstream of the $m t r E$ stop codon is notable (Fig. 2). The repeated unit, containing highly conserved 26 bp inverted repeats at either end of the sequence, was originally reported by Correia et al. (1988). The repetitive sequence was indigenous to the pathogenic Neisseria, occurring in at least 20 locations in the genome. The sequence from $N$. meningitidis recently reported by Abadi et al. (1996) contains a similar element downstream of the region containing the promoters for $m t r R$ and $m t r C$. This region, spanning $m t r R$, its promoter region and the $5^{\prime}$ end of $m t r C$, was otherwise $97 \cdot 2 \%$ identical to the gonococcal sequence. The relevance of these elements has not been determined; however, in the meningococcus it could potentially function in a regulatory capacity by displacing the structural $m t r C$ gene from its transcriptional promoter (W. M. Shafer, unpublished observations). The elements are potentially equipped with their own promoters (Correia et al., 1988), and could direct transcription of the structural efflux genes independently, thereby relieving repression due to MtrR. The element associated with the meningococcal $m t r R$ is inverted with respect to the element downstream of $m t r E$ in the gonococcus (Fig. 2). It is presently unknown if a similarly inverted sequence is present downstream of the meningococcal $m t r E$ gene. Should this be the case, then transcription of the structural genes $m t r C D E$ could be further modulated with respect to repression by $m t r R$ by recombinational events involving the two elements.

\section{ACKNOWLEDGEMENTS}

R.M.D. gratefully acknowledges the support and encouragement of Ivor Brown and Martin Gill. This work was supported by grants from the Joint Standing Research Committee, St Mary's Hospital (C.A.I.) and NIH grant AI21150 (W.M.S.). B.D.R. is in receipt of a Research Career Development Fellowship from the Wellcome Trust. W.M.S. is the recipient of an Associate Career Scientist Award from the VA Medical Research Service.

\section{REFERENCES}

Abadi, F. J. R., Carter, P. E., Cash, P. \& Pennington, T. H. (1996). Rifampin resistance in Neisseria meningitidis due to alterations in membrane permeability. Antimicrob Agents Chemother 40, 646-651.

Brendel, V., Bucher, P., Nourbakhsh, I. R., Blaisdell, E. \& Karlin, S. (1992). Methods and algorithms for statistical analysis of protein sequences. Proc Natl Acad Sci USA 89, 2002-2006.

Burns, J. L., Wadsworth, C. D., Barry, J. J. \& Goodall, C. P. (1996). Nucleotide sequence analysis of a gene from Burkbolderia (Pseudomonas) cepacia encoding an outer membrane lipoprotein involved in multiple antibiotic resistance. Antimicrob Agents Chemother 40, 307-313.

Chou, P. Y. \& Fasman, G. D. (1978). Empirical prediction of protein conformation. Annu Rev Biochem 47, 251-276.

Correia, F. F., Inouye, S. \& Inouye, M. (1988). A family of small repeated elements with some transposon-like properties in the genome of Neisseria gonorrboeae. J Biol Chem 263, 12194-12198.

Devereux, J., Haeberli, P. \& Smithies, O. (1984). A comprehensive set of sequence analysis programs for the VAX. Nucleic Acids Res 12, 387-395.

Economou, A., Hamilton, W. D. O., Johnston, A. W. B. \& Downie, J. A. (1990). The Rbizobium nodulation gene nodO encodes a $\mathrm{Ca}^{2+}$-binding protein that is exported without $\mathrm{N}$-terminal cleavage and is homologous to haemolysin and related proteins. $E M B O J$ 9, 349-354.

Fath, M. J. \& Kolter, R. (1993). ABC transporters: bacterial exporters. Microbiol Rev 57, 995-1017.

Fralick, J. A. \& Burns-Keliher, L. L. (1994). Additive effect of tolC and $r f a$ mutations on the hydrophobic barrier of the outer membrane of Escherichia coli K-12. J Bacteriol 176, 6404-6406.

Garnier, J., Osguthorpe, D. J. \& Robson, B. (1978). Analysis of the accuracy and implications of simple methods for predicting the secondary structure of globular proteins. J Mol Biol 120, 97-120.

Goodman, S. D. \& Scocca, J. J. (1988). Identification and arrangement of the DNA sequence recognised in specific transformation of Neisseria gonorrhoeae. Proc Natl Acad Sci USA 85, 6982-6986.

Guymon, L. F., Walstad, D. L. \& Sparling, P. F. (1978). Cell envelope alterations in antibiotic-sensitive and -resistant strains of Neisseria gonorrhoeae. J Bacteriol 136, 391-401.

Hagman, K. E. \& Shafer, W. M. (1995). Transcriptional control of 
the $m$ tr efflux system of Neisseria gonorrhoeae. J Bacteriol 177, 4162-4165.

Hagman, K. E., Pan, W., Spratt, B. G., Balthazar, J. T., Judd, R. C. \& Shafer, W. S. (1995). Resistance of Neisseria gonorrhoeae to antimicrobial hydrophobic agents is modulated by the $m t r R C D E$ efflux system. Microbiology 141, 611-622.

Hayashi, S. \& Wu, H. C. (1990). Lipoproteins in bacteria. J Bioenerg Biomembr 22, 451-471.

Kyte, J. \& Doolittle, R. F. (1982). A simple method for displaying the hydropathic character of a protein. J Mol Biol 157, 105-132.

Lucas, C. E., Hagman, K. E., Levin, J. C., Stein, D. C. \& Shafer, W. M. (1995). Importance of lipooligosaccharide structure in determining gonococcal resistance to hydrophobic antimicrobial agents resulting from the $m t r$ efflux system. Mol Microbiol 16, 1001-1009.

Ma, D., Cook, D. N., Alberti, M., Pon, N. G., Nikaido, H. \& Hearst, J. E. (1993). Molecular cloning and characterisation of $a c r A$ and acrE genes of Escherichia coli. J Bacteriol 175, 6299-6313.

Ménard, R., Sansonetti, P. J. \& Parsot, C. (1993). Nonpolar mutagenesis of the ipa genes defines IpaB, IpaC, and IpaD as effectors of Shigella flexneri entry into epithelial cells. J Bacteriol 175, 5899-5906.

Morona, R., Manning, P. A. \& Reeves, P. (1983). Identification and characterization of the TolC protein, an outer membrane protein from Escherichia coli. J Bacteriol 153, 693-699.

Morse, S. A., Lysko, P. G., McFarland, L., Knapp, J. S., Sandstrom, E., Critchlow, C. \& Holmes, K. K. (1982). Gonococcal strains from homosexual men have outer membranes with reduced permeability to hydrophobic molecules. Infect Immun 37, 432-438.

Nikaido, H. (1994). Prevention of drug access to bacterial targets: permeability barriers and active efflux. Science 264, 382-387.

Nikaido, H. \& Saier, M. H., Jr (1992). Transport proteins in bacteria: common themes in their design. Science 258, 936-942.

Pan, W. \& Spratt, B. G. (1994). Regulation of the permeability of the gonococcal cell envelope by the $m t r$ system. Mol Microbiol 11, 769-775.
Poole, K., Krebes, K., McNally, C. \& Neshat, S. (1993). Multiple antibiotic resistance in Pseudomonas aeruginosa: evidence for involvement of an efflux operon. J Bacteriol 175, 7363-7372.

Rost, B. \& Sander, C. (1993). Prediction of protein secondary structure at better than 70\% accuracy. J Mol Biol 232, 584-599.

Saier, M. H., Jr, Tam, R., Reizer, A. \& Reizer, J. (1994). Two novel families of bacterial membrane proteins concerned with nodulation, cell division and transport. Mol Microbiol 11, 841-847.

Shafer, W. M., Guymon, L. F., Lind, I. \& Sparling, P. F. (1984). Identification of an envelope mutation $(e n \nu-10)$ resulting in increased antibiotic susceptibility and pyocin resistance in a clinical isolate of Neisseria gonorrboeae. Antimicrob Agents Chemother 25, 767-769.

Shafer, W. M., Balthazar, J. T., Hagman, K. E. \& Morse, S. A. (1995). Missense mutations that alter the DNA-binding domain of the MtrR protein occur frequently in rectal isolates of Neisseria gonorrboeae that are resistant to faecal lipids. Microbiology 141, 907-911.

Sparling, P. F., Sarubbi, F. A., Jr \& Blackman, E. (1975). Inheritance of low-level resistance to penicillin, tetracycline, and chloramphenicol in Neisseria gonorrboeae. J Bacteriol 124, 740-749.

Stern, A., Nickel, P., Meyer, T. F. \& So, M. (1984). Opacity determinants of Neisseria gonorrboeae: gene expression and chromosomal linkage to the gonococcal pilus gene. Cell 37, $447-456$.

Surin, B. P., Watson, J. M., Hamilton, W. D., Economou, A. \& Downie, J. A. (1990). Molecular characterisation of the nodulation gene, nodT, from two biovars of Rhizobium leguminosarum. Mol Microbiol 4, 245-252.

Wang, R. C., Seror, S. J., Blight, M., Pratt, J. M., Broome-Smith, J. K. \& Holland, I. B. (1991). Analysis of the membrane organization of an Escherichia coli protein translocator, HlyB, a member of a large family of prokaryote and eukaryote surface transport proteins. J Mol Biol 217, 441-454.

Received 5 December 1996; revised 20 February 1997; accepted 3 March 1997. 